\title{
Hundred years of Botany at the NWU: contributions towards understanding plant and algae function, diversity and restoration in a changing environment
}

\section{Authors}

'S.S. Cilliers (1)

S. Janse van Vuuren

'K. Kellner (1)

${ }^{1}$ G.H.J. Krüger (1)

${ }^{1} \mathrm{M}$. Struwig (B)

${ }^{2}$ C.J.G van Niekerk

'S.J. Siebert (1)

\section{Affiliations}

'Unit for Environmental Sciences and Management, North-West University, Private Bag X6001, Potchefstroom 2520, South Africa.

${ }^{2}$ NWU Botanical Garden, North-West University, Private Bag X6001, Potchefstroom 2520

\section{Corresponding Author}

Prof. Sarel S. Cilliers Sarel.Cilliers@nwu.ac.za

\section{Dates}

Accepted: 13 October 2020 Published: 24 February 2021

\section{How to cite this article:}

Cilliers, S.S., Janse van Vuuren S., Kellner, K., Krüger, G.H.J., Struwig, M., Van Niekerk,

C.J.G. \& Siebert, S.J., 2021 'Hundred years of Botany at the NWU: contributions towards understanding plant and algae function, diversity and restoration in a changing environment', Bothalia 51(1), a2. http://dx.doi.org/10.38201/btha. abc.v51.i1.2
The Department of Botany on the Potchefstroom Campus (formerly Potchefstroom University for Christian Higher Education) of the North-West University (NWU) had its centenary in 2020.

In this paper we celebrate this milestone by giving an overview of the history of the Department at this campus, including its recent establishment and expansion on the NWU Mahikeng Campus (formerly the University of North-West). A brief overview is presented of the advances in teaching and research over the years, and the development and relevance of the important plant collections in the botanical garden, two herbaria and the national diatom collection.

The main emphasis of this contribution is, however, a reflection on the advancement and significance of research conducted by various disciplines on plant and algae function, diversity and ecological restoration over the years.

The different disciplines in Botany at NWU, from the oldest to the more recent, are Plant Taxonomy, Plant Ecophysiology, Terrestrial Plant Ecology, Aquatic Sciences, Urban and Settlement Ecology, Geoecology, and Proteomics.

Different aspects contributing to changes occurring in the environment, such as pollution, land degradation, urbanisation, overexploitation of resources and the subsequent effect of these on plant diversity and function are especially addressed in our current research. The results of our research inter alia led to solutions for problems occurring in the landscape and contribute to the well-being of the people using the land and water by restoring important ecosystem services.

Keywords: Aquatic sciences, geoecology, plant ecophysiology, proteomics, taxonomy, terrestrial plant ecology, urban and settlement ecology.

\section{Introduction}

The Botany Department of the former Potchefstroom University for Christian Higher Education (PU for CHE) (now part of the North-West University) was 100 years old in 2020. To celebrate this milestone this special issue of Bothalia - African Biodiversity and Conservation was initiated. The aim of the present paper is to provide an overview of the 100-year history of the Botany Department and the botanical garden at this institution, and also to highlight research in the different disciplines and their contribution towards knowledge on plant and algae function, diversity and ecology. Most of the current research has focused on addressing the negative effects associated with land-use changes. As this is not intended to be a complete review of each research discipline, 
only few of the most important research papers are highlighted. The other contributions in this special issue will focus on specific current research projects in the Department.

\section{Brief History of the Department of Botany at NWU}

A century ago it was not unusual to find Botany students attending lectures in an old stable in Potchefstroom (Figure 1) on the premises of the house of Marthinus Wessel Pretorius, former president of the South African Republic/Zuid-Afrikaansche Republiek (in the 1880s). This is where Botany found its humble beginnings in the earlier years of the PU for $\mathrm{CHE}$. On sunny days, practical classes were conducted under the oak trees (Quercus robur L.) in the garden, which are still today silent witnesses of those earlier 'aha!' experiences so typical of studies of the plant kingdom. Botany later moved to the more luxurious, old prefabricated military barracks that were erected on the main university campus in Potchefstroom (Jooste 2017). Subsequently, Botany has since relocated twice, and today has excellent facilities including laboratories, a botanical garden, herbaria, ecological research sites, green houses and open-top growth chambers, all state of the art.

Initially, in 1920, Botany and Zoology courses were presented by one lecturer, but five years later a dedicated lecturer for Botany, Mildred Radloff (Figure 2), was appointed. She had to carry a full load of lecturing and presenting practical classes for all three pre-graduate year groups until 1931 when she married and had to resign due to the protocol of the University at that time. The first professor and head of department was Antonie Goossens (Figure 3) and with his appointment (1932-1961) a new phase started for Botany, with the first master's degree student (Mr W.J. Stapelberg) enrolling in 1933. Goossens was dedicated to develop Afrikaans terminology for Botany and he and a colleague, Piet Botha, published the first comprehensive Botany textbook in Afrikaans, Leerboek vir Plantkunde, in 1944, which was used at all the Afrikaans universities until 1971. He also published the first Afrikaans key to the families and genera of flowering plants of South Africa (1940), and compiled the first English-Afrikaans/ Afrikaans-English botanical dictionary (1972).

Botha became the next head of department (19621972). He specialised in plant physiology under guidance of the renowned plant physiologist Prof Karl Wetzel of the Friedrich Wilhelm University, but due to the outbreak of World War II in 1939, he had to flee Germany. He completed his doctorate through the University of South Africa (UNISA). Another botanist at the PU for $\mathrm{CHE}$ who was affected by the war was Max Papendorf (later the third head of department; 1973-1982). He had earlier completed an excellent master's study under Goossens. Papendorf had received the George Grey bursary to study abroad but was prevented by the outbreak of the Second World War (Jooste 2017).

Daan Botha was appointed as the fourth head of department (1983-1985) and he will be remembered for his initiative to change the veld garden into a botanical

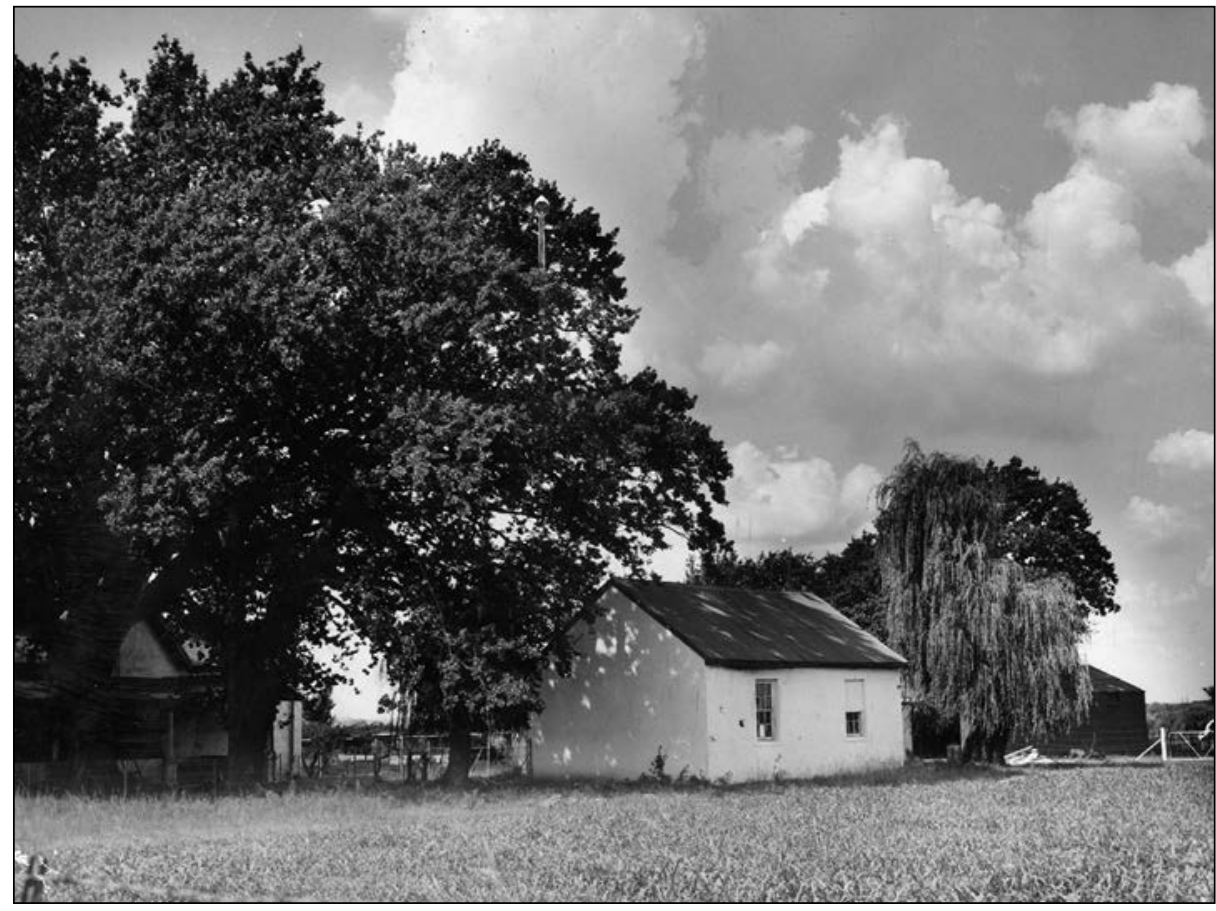

Figure 1. First lecture room for Botany - a stable (Source: NWU Records, Archives and Museum). 


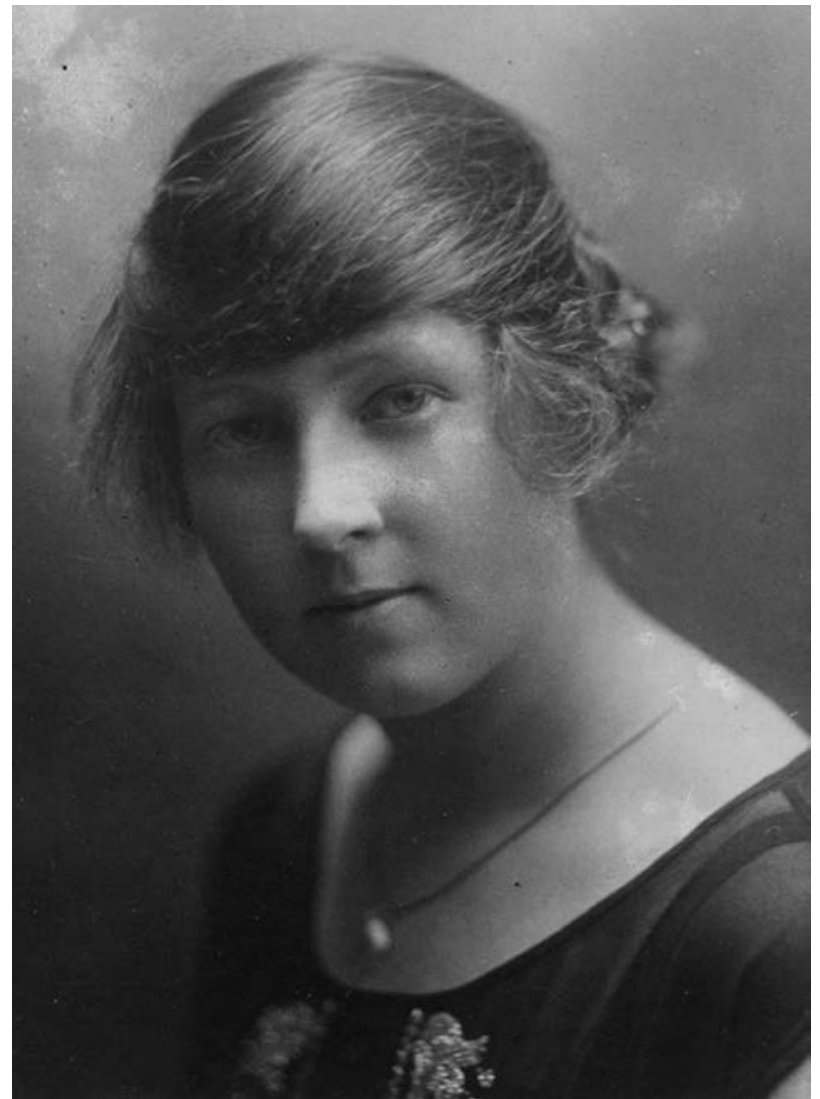

Figure 2. Miss Millie Radloff, first lecturer in Botany (Source: NWU Records, Archives and Museum).

garden, which is now a living legacy. Botha left in 1985 and became the Director of the National Botanical Gardens of the National Botanical Institute (later South African National Biodiversity Institute). His successor, Ockie Bosch (1986-1993), focused on establishing an integrated approach in the teaching of Botany, which culminated in significant changes to the curricula and a name change from the Department of Botany to the Department of Plant Sciences, in accordance to international trends at the time. Five years later another name change followed when Soil Sciences merged with Plant Sciences to become the Department of Plant and Soil Sciences. This led to further changes in the curricula to ensure that plant and soil sciences complemented each other at honours level so that postgraduate students could specialise in resource development, horticultural sciences, pasture ecology or plant pathology. When Braam Pieterse became the sixth head of department (1994-1997), the integrated approach was phased out, and eventually he reinstated the Botany Department with focus on the sub-disciplines of Botany (Jooste 2017).

In 1996 the University embarked on the formation of different Schools and Botany became one of six subject groups in the School of Environmental Sciences and Development. No major changes occurred in the undergraduate courses, but at postgraduate level the

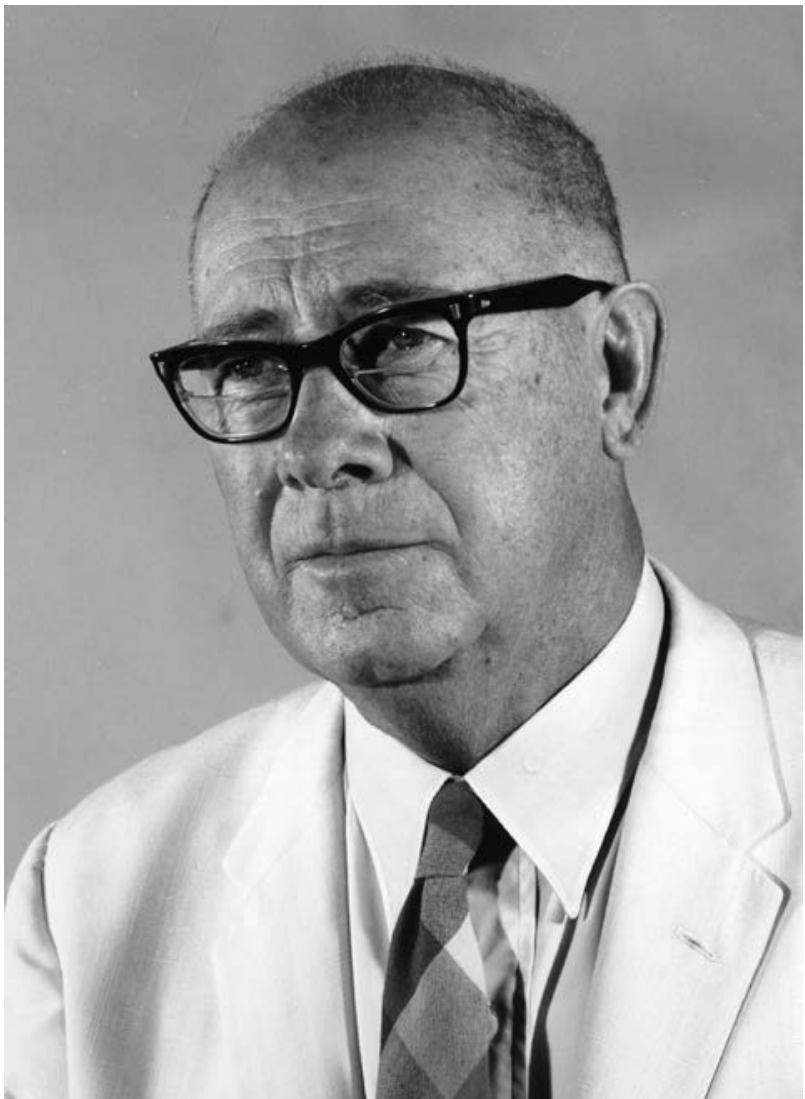

Figure 3. Prof. A.P Goossens, first Professor and Head of Department of Botany (Source: NWU Records, Archives and Museum).

focus was placed on Environmental Sciences and botany lecturers contributed to integrated courses in different streams, namely Ecological Remediation and Sustainable Management, Biodiversity and Conservation Biology and Water Sciences. Since 1998, the subject group Botany was led by chairs on a rotational basis (Gert Krüger (1998-2002), Sarel Cilliers (2003-2006 and 2009-2013), Klaus Kellner (2007-2008), Sanet Janse Van Vuuren (2014-2016), Stefan Siebert (20172019) and currently Sandra Barnard (2020-). In 2004 the PU for CHE merged with the former University of North-West and the Sebokeng campus of the Vista University to form the North-West University with three campuses (Potchefstroom, Mahikeng and Vanderbijlpark) and eight faculties.

In 2012 the School of Environmental Sciences and Development split into two new Schools and Botany became part of the School of Biological Sciences (Jooste 2017). Postgraduate studies were divided into different subprogrammes and Botany staff and students contribute to Aquatic Ecosystem Health, Biodiversity and Conservation Ecology as well as Ecological Interactions and Ecosystem Resilience (Jooste 2017). In 2017 the Botany subject group expanded to the Mahikeng campus. Subsequently, major changes in the undergraduate courses had to be implemented to align the Botany modules between campuses. 


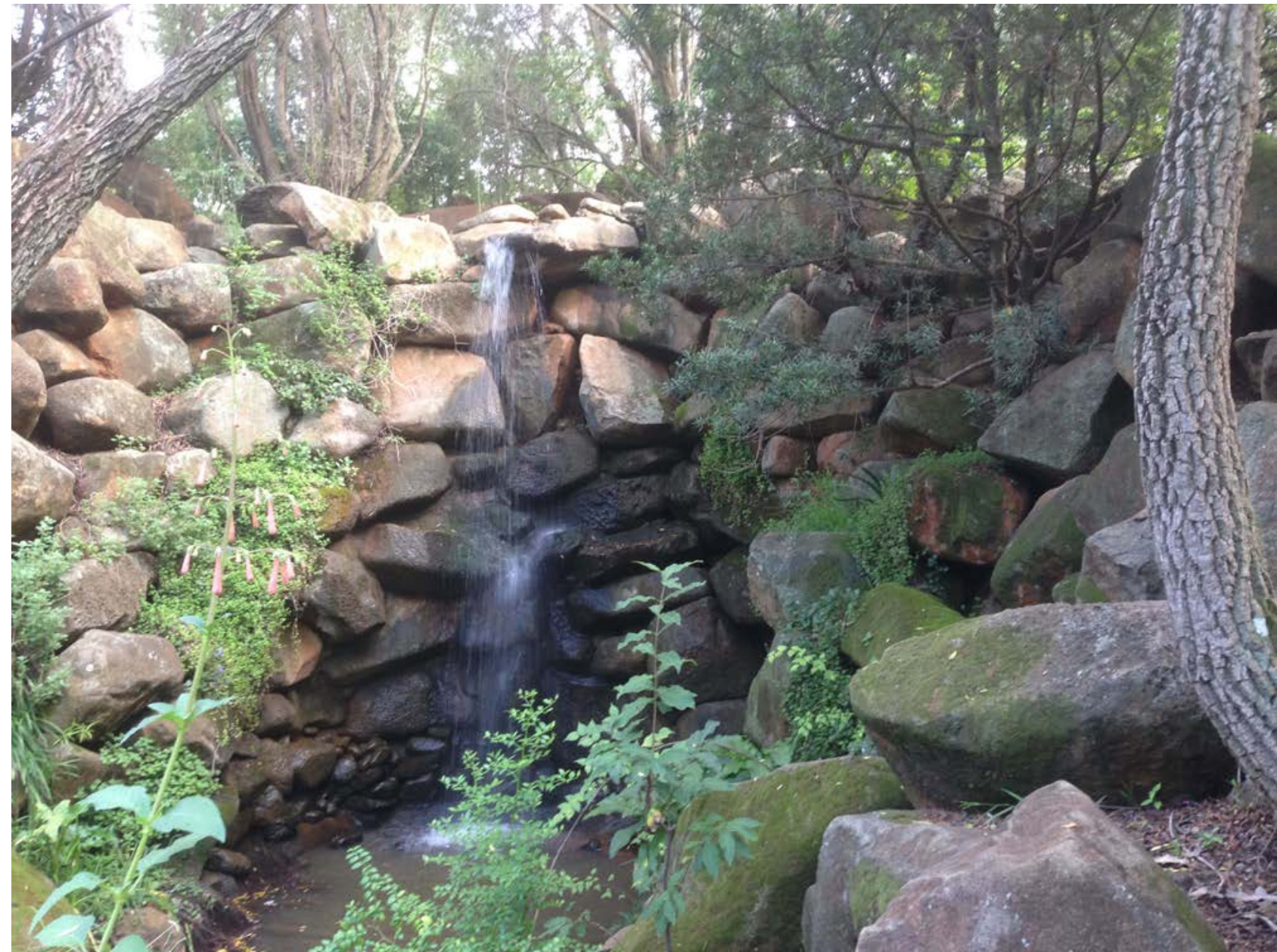

Figure 4. Botanical Garden - Waterfall on Prof. Daan Botha's koppie. (Photo: Chris van Niekerk from NWU Botanical Garden collection).

Although Botany curricula have been changed quite drastically over the years there was always a constant stream of students interested in Botany. Enrolled student numbers averaged 113, 61 and 37 for Botany I, II and III respectively since 2010 . Botany has also been phased in successfully on the Mahikeng campus and in 2020 we have enrolled 123, 56 and 55 students for Botany I, II and III respectively. Post-graduate training has always been an important focus for the Botany Department. Over the last ten years, 105 Masters and 25 PhD students were supervised in different disciplines of Botany at the NWU.

Both past and current alumni are well known names in the South African Botany community. The list is long and here we list only those with postgraduate degrees from the department who became professors at other universities - Manie van der Schijff, Albert Eicker, Braam van Wyk (all Pretoria), Kobus Eloff, Braam Pieterse, Amie van der Westhuizen (all Free State), Jan de Bruin, Johan Visser, Frikkie Botha, Anna-Maria Botha (all Stellenbosch), and Ockie Bosch (University of Queensland, Australia) (Jooste 2017). Botany alumni are also employed outside academia in various sectors (often in senior positions) - Agricultural Research Council, Department of Environment, Forestry and Fisheries, Eskom, MidVaal Water Company,
North-West Province Agriculture, Rand Water, South African Environmental Observation Network, South African National Biodiversity Institute, South African Sugar Research Institute, and various botanical gardens, private environmental consultation firms and NGOs.

\section{Brief History of the NWU Botanical Garden}

The origins of the NWU Botanical Garden (Figure 4) may be traced back to 1925, when Radloff was appointed as the first Botany lecturer at the Potchefstroom University. She was responsible for the collection of fresh plant material for practical sessions, and the Botanical Garden would eventually grow due to this need for plant material - and it remains one of the key functions of the garden to this day.

However, it was several decades later, in the early 1960s, that the first steps were taken by Goossens to initiate a garden. At the insistence of Goossens, Wynand Louw was appointed in 1962 as a taxonomist and Botany lecturer, and one of his first tasks was to develop 
Table 1. Founders and curators of the plant collections of the Potchefstroom and Mahikeng campuses of the North-West University since 1932

\begin{tabular}{llll}
\hline Curator & Period & Years & Collection \\
\hline Antonie P. Goossens $^{\mathrm{F}}$ & $1932-1961$ & 29 & Herbarium of the PU for CHE (PUC) \\
\hline Wynand J. Louw & $1962-1970$ & 8 & PU for CHE Veld Garden \\
\hline Daniel J. Botha & $1971-1985$ & 14 & Herbarium of the PU for CHE (PUC) \\
\hline Bert Ubbink & $1973-1990$ & 17 & PU for CHE Botanical Garden \\
\hline Sello D. Phalatse & $1983-2008$ & 25 & University of North-West Herbarium (UNWH) \\
\hline Gideon F. Smith & $1986-1992$ & 6 & Herbarium of the PU for CHE (PUC) \\
\hline Daniël J. Theunissen & $1993-1997$ & 4 & Herbarium of the PU for CHE (PUC) \\
\hline Matthias H. Buys & $1998-2006$ & 8 & A.P. Goossens Herbarium (PUC) \\
\hline Peter Mortimer & $2003-2006$ & 3 & North-West University Botanical Garden \\
\hline Stefan J. Siebert & $2007-$ present & 14 & A.P. Goossens Herbarium (PUC) \\
\hline Martin F. Smit & $2007-2011$ & 4 & North-West University Botanical Garden \\
\hline Jonathan C. Taylor & 2009-present & 11 & South African National Diatom Collection (SANDC) \\
\hline Pieter W. Malan & $2009-2016$ & 7 & University of North-West Herbarium (UNWH) \\
\hline Christiaan J.G. van Niekerk & $2012-$ present & 9 & North-West University Botanical Garden \\
\hline Madeleen Struwig & $2017-$ present & 4 & S.D. Phalatse Herbarium (UNWH) \\
\hline
\end{tabular}

FFounder, ${ }^{\mathrm{B}}$ Renamed collection, ${ }^{\mathrm{C}}$ Founder of the botanical garden

a garden to grow plant material for practical classes. Louw identified a piece of land in the northern part of the campus and started to develop a veld garden to supply fresh plant material over the next eight years, until 1970, when he left the university.

The idea to develop a proper botanical garden came in 1971, with the appointment of Daan Botha as plant taxonomy lecturer and curator of the herbarium (Table 1). In 1972 he appointed the garden's first horticulturist, Derick Pitt, to help with the development and maintenance of the garden. Pitt left the garden within a year after his appointment and Bert Ubbink, a horticulturist from the University of Pretoria, was appointed as the first permanent curator of the garden in 1973. Ubbink was responsible for the design, layout and construction of the pathways and the water ponds throughout the garden.

During the early 1990s, the University drastically reduced funding of the Botanical Garden and there was a shift in focus to more integrated teaching and research. The maintenance of the Botanical Garden was transferred to the campus garden services and the Garden curator was redeployed to the Technical Services Department on campus. This was the start of a period of tragic neglect of the Garden. Over the next decade, the Garden and buildings deteriorated to a state of dilapidation and an overgrown piece of veld.

The recovery and revival of the Botanical Garden started in 2003 with the appointment of a new curator,
Peter Mortimer. Under the leadership of Mortimer, the deteriorated structures were repaired, unwanted trees were removed, and new flower beds were designed and constructed.

After the aforementioned merger of universities in 2004, Annette Combrink, rector of the Potchefstroom campus, recognised the important role of the Botanical Garden for community education, capacity building, and for promoting the image of the NWU. Martin Smit succeeded Mortimer as the Garden curator (2007-2011), and he sourced funds through Combrink to further improve the Botanical Garden. Smit and his team made huge improvements to the garden design and layout (Smit et al. 2011). The current curator of the Garden, Chris van Niekerk, was appointed on 1 November 2011, and is implementing Smit's vision to expand the plant collections and to make the Botanical Garden a multi-disciplinary experience. To achieve this the garden added a geological display in a geological rock garden representing a walk back in time through rocks exposed in the 2023 million year old Vredefort meteorite impact structure and a site-specific digital literature experience called 'Byderhand'.

The living plant collection in the Garden represents species from 105 families. Rare species such as Brachystelma barberae Harv. ex Hook.f., Clivia mirabilis Rourke, Prototulbaghia siebertii Vosa, Searsia batophylla (Codd) Moffett and Welwitschia mirabilis Hook.f., serve as reference collections for research projects (Berner et 
al., 2020). The Garden not only supports training and research of students within the NWU, but it also focusses on ex situ conservation of various species. More than 2000 individuals of the endemic Khadia beswickii (L.Bolus) N.E.Br. (Van Niekerk \& Siebert 2018) and various other species of special interest, such as Boophone disticha (L.f.) Herb. and Nananthus vittatus (N.E.Br.) Schwantes, have been rescued, relocated and monitored due to destruction of their natural habitat.

\section{Different Research Disciplines in Botany}

\section{Plant taxonomy}

Plant taxonomic research at the Potchefstroom campus dates back to the early 1930s. The first taxonomic work was conducted by Antonie Goossens (Figure 2) who focussed on grasses from the Potchefstroom region. This eventually led to the description of the genus Bewsia Gooss. (Goossens 1941) and several grass species new to science, for example Anthephora argentea Gooss., Enneapogon spathaceus Gooss., Sporobolus bechuanicus Gooss., Styppeiochloa gynoglossa (Gooss.) De Winter, Tarigidia aequiglumis (Gooss.) Stent and Urochloa stolonifera (Gooss.) Chippind. (Goossens \& Philips 1932). The Herbarium of the PU for CHE was founded by Goossens in 1932. The herbarium was later renamed in his honour by the sixth curator, Matt Buys (Table 1), and officially became the A.P. Goossens Herbarium. Today it holds over 30000 specimens for educational and research purposes.

In the 1960s, Wynand Louw succeeded Goossens as taxonomist and discovered many new species of succulents, of which Euphorbia louwii L.C.Leach commemorates his life-long dedication. From 1970 to mid-1980s, Daan Botha was the resident plant taxonomist and under his supervision various taxonomic studies were conducted on a range of genera, such as Antizoma (Menispermaceae), Brachylaena (Asteraceae), Crabbea (Acanthaceae), Eugenia (Myrtaceae), Sphedamnocarpus (Malphigiaceae) and Vitex (Lamiaceae). Various taxonomic changes were proposed (e.g. Bredenkamp \& Botha 1993). Gideon Smith succeeded Botha in 1986, and like Louw, was a succulent devotee with a research interest in the Asphodelaceae, Crassulaceae and Mesembryanthemaceae (now Aizoaceae), which subsequently led to the revision of several genera in later years. Both Botha and Smith moved on to head up directorates at the National Botanical Institute (later South African National Biodiversity Institute).

During this period the University of North-West herbarium (UNWH) was established in Mahikeng by David Phalatse (Figure 5). He established the herbarium in 1983 as a teaching facility for the Biology Department at the then University of Bophuthatswana. This herbarium became part of the University of North-West and later the North-West University during the amalgamation in 2004. With the introduction of Botany as subject on the Mahikeng campus in 2017, it was incorporated into the subject group of Botany and was renamed the S.D. Phalatse Herbarium by the third curator, Madeleen Struwig (Table 1). The collection is fast approaching 1000 specimens and will be expanded considerably to meet the educational and research demands of the Mahikeng campus. Like the A.P. Goossens Herbarium, it also serves as a voucher repository for various disciplines studying plants, their products and applications beyond pure botanical studies.

In the mid-1990s, Danie Theunissen combined his ecological and taxonomical knowledge to identify grass ecotypes for application in agriculture and rehabilitation, which culminated in a range of ecosystematic accounts of ecotypes in grass genera such as Digitaria, Eragrostis, Setaria and Themeda (Theunissen 1992). Matt Buys was taxonomist from 1998 to 2006 and had a keen interest in the genera Lobostemon (Boraginaceae), for which he described various new taxa, and the phylogeny of Delosperma (Aizoaceae). Under his supervision the genera Drimiopsis (Hyacinthaceae) (Lebatha et al. 2006), and Ruschia (Aizoaceae) were revised. He is currently the curator of Scion's National Forestry Herbarium in New Zealand.

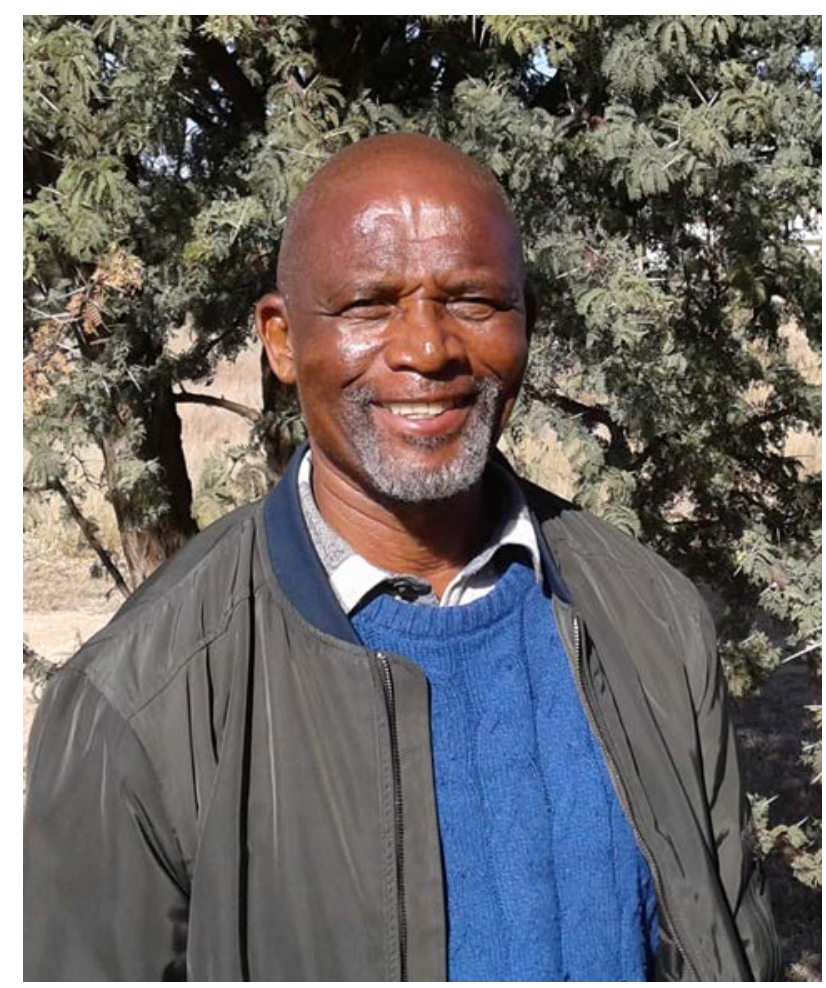

Figure 5: Mr Sello D. Phalatse, first Botanist at Mahikeng Campus (1983-2008), founder and curator of the University of North-West Herbarium (Source: NWU Records, Archives and Museum) (Source: NWU Corporate Relations and Marketing). 
Since 2007 taxonomic work has mainly focussed on Boerhavia and Commicarpus in the Nyctaginaceae (Struwig \& Siebert 2013). The two genera were revised for the first time in southern Africa and resulted in the description of a new species, B. orbicularifolia Struwig, and a new variety, C. squarrosus (Heimerl) Standl. var. fruticosus (Pohn.) Struwig (Struwig \& Siebert 2013). Floristic studies have also led to the description of rare and endemic species from Sekhukhuneland in Limpopo (Siebert et al. 2010), such as Euclea sekhukhuniensis Retief, S.J.Siebert \& A.E.van Wyk (Ebenaceae), Pavetta glaucophylla Retief, S.J.Siebert \& A.E.van Wyk (Rubiaceae), and Polygala sekhukhuniensis Retief, S.J.Siebert \& A.E.van Wyk (Polygalaceae). With the advent and development of Botany as a subject on the Mahikeng campus in 2017, taxonomic research has gained momentum under Struwig and various revisions are currently underway on members of the Molluginaceae.

To strengthen taxonomic research at the NWU, two extraordinary lecturing appointments were made of taxonomists employed by the South African National Biodiversity Institute. Pieter Bester was appointed to the Potchefstroom Campus from 2013 and Marinda Koekemoer to the Mahikeng Campus from 2019. Bester is an expert on the Apocynaceae and Koekemoer on the Asteraceae. Their knowledge of the diagnostic characters of plant families, and development of educational material for use in practical plant identification have greatly contributed to the training of undergraduate students studying the flora of South Africa.

Taxonomy at NWU has contributed to the national effort to categorise and name plants. The major focus has been on the Poaceae, and specialist interest in the Apocynaceae and Nyctaginaceae (Bester \& Nicholas 2018, Struwig \& Siebert 2013). The specific focus on grasses in both herbaria has enabled other botanical fields studying land-use change in the Grassland and Savanna biomes to identify and measure character traits of the fundamental units of biodiversity, namely the species. The A.P. Goossens Herbarium holds an actively utilised, ornamental plant collection of close to 2500 specimens originating from an urbanisation gradient stretching from rural villages to the Johannesburg metropole. It also keeps large ecological voucher collections (> 20000 specimens) of the Potchefstroom region to Vredefort Dome (both the Dry and Mesic Highveld Grassland Bioregions), Ganyesa to Griqualand-West (Eastern Kalahari Bushveld Bioregion), and Dwarsberg to Impala Platinum (Central Bushveld Bioregion). In recent years, taxonomists on both campuses have contributed to new research in Botany that focuses on the taxonomical and functional trait diversity of forbs across land-uses in grassy biomes (Siebert et al. 2021). To support this initiative, a large collection of forbs from the Lowveld Bioregion has been collected over a decade.

\section{Plant ecophysiology}

Piet Botha established the plant physiology discipline in 1937. The theme of Botha's PhD degree from the University of South Africa was the biology of the plant parasite Alectra vogelii Benth. (Botha 1950). He was the director of the Institute for Plant Physiological Research at PU for CHE, which was established in 1949, and which later became the Institute for Botanical Research in 1970. Charles Whitehead (appointed as lecturer/associate professor in 1977) investigated ethylene sensitivity in plant tissues to elucidate the mechanisms involved in the control of senescence and ripening in plants with the view to develop effective methods to delay senescence and ripening of fruits and vegetables (Whitehead et al. 1984).

Since the appointment of Gert Krüger in 1988, the focus of research in plant physiology was directed at studying the physiological and biochemical basis of the response of crop plants and natural vegetation to environmental stress. The research, with an integrative approach, involved studying plant responses on a reductionist as well as on a whole-plant level, ideally suited to the teaching of the principles of plant physiology. The key feature facilitating research on plant responses was the outstanding laboratories for the study of the ecophysiology and biochemistry of photosynthesis, and facilities to grow plants under strictly controlled conditions, such as a state-of-the-art open-top chamber facility (OTC) (Figure 6) for studying air pollution effects.

In an endeavor to determine the physiological parameters that could be used as drought tolerance selection criteria for different tobacco cultivars, the effect of induced drought was studied in depth through its effect on photosynthetic gas exchange (Van Rensburg \& Krüger 1993a), oxidative stress metabolism, accumulation of secondary metabolites such as proline and abscisic acid (Van Rensburg \& Krüger 1993b) and osmoregulation, by postgraduate student and later Research Director: Unit for Environmental Sciences and Management, NWU, Leon van Rensburg. During this time supportive research on the anatomical and cytological anomalies found in studies of water stress on plants was done by Hester Kruger.

Pioneering studies on the application of prompt chlorophyll a fluorescence induction for assessing photosynthetic potential and vitality of test plants subjected to environmental stress were undertaken in close collaboration with the international expert on chlorophyll a fluorescence kinetics, Reto Strasser, University of Geneva. By analysing fluorescence transients of plants exposed to different light regimes according to the so-called JIP-test, deconvoluting the behavior of PSII into several functional and structural parameters, it was demonstrated that these parameters undergo differential changes upon a particular stress. The JIP-test is now 


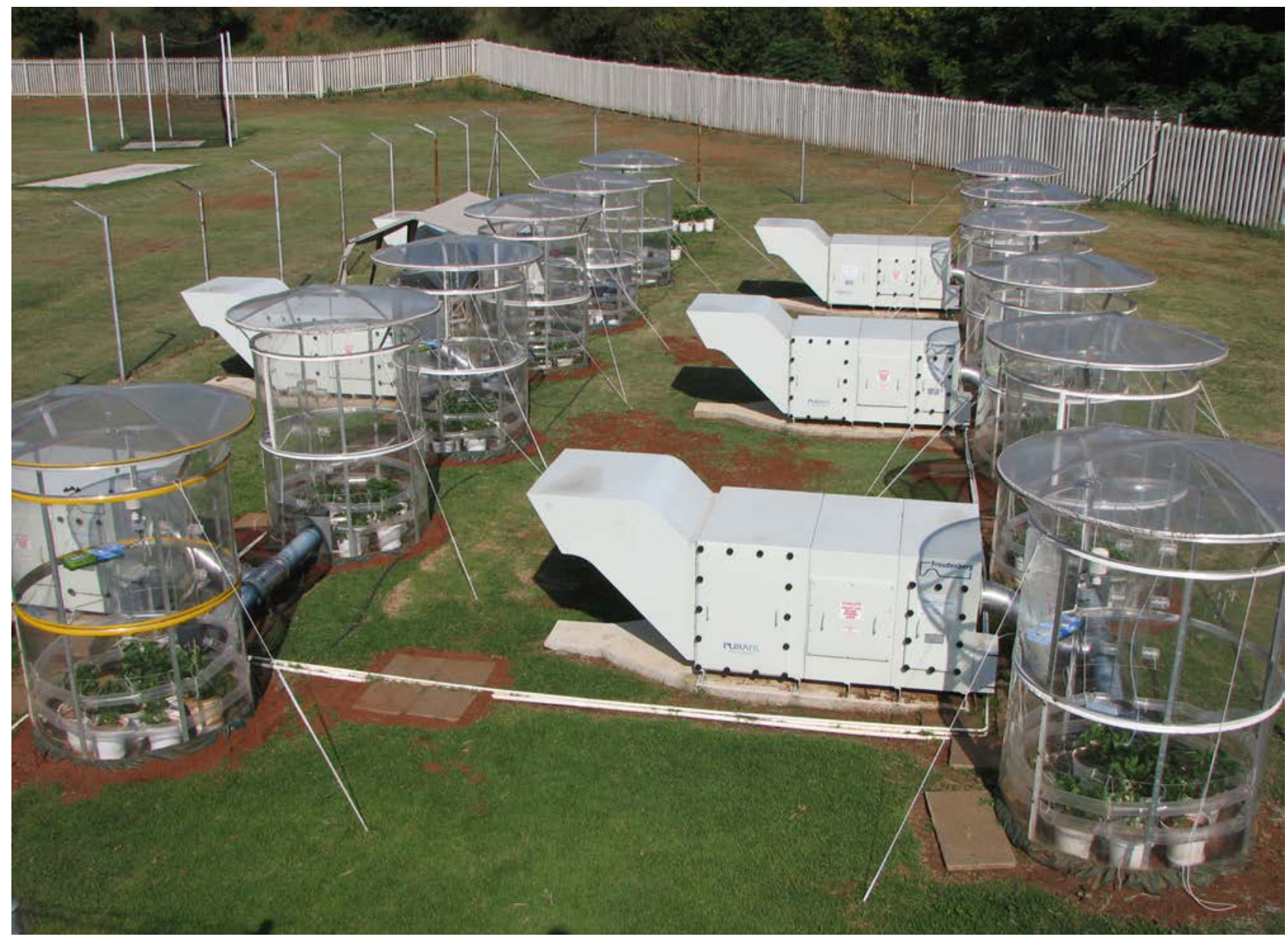

Figure 6. State-of-the-art open top chambers for research in ecophysiology (Photo: Jacques Berner).

used all over the world and the paper by Botany staff is regarded as a standard document (Krüger et al. 1997). Further technical developments of the JIP-test were illustrated by several papers on chilling stress in soybean.

Riekert van Heerden joined the department as plant physiologist in the mid-1990s and his doctoral studies on various aspects of chilling stress in soybean culminated in several key publications. With the aim to identify the traits that convey dark chill stress tolerance various approaches were employed, such as determining the effect of separately and simultaneously induced dark chilling and drought stress on photosynthesis, the monitoring in parallel of $\mathrm{CO}_{2}$-assimilation, O-J-I-P chlorophyll fluorescence kinetics and nitrogen fixation of test plants, and assessing the constraints on Calvin-Benson cycle metabolism (Van Heerden et al. 2003). An outstanding practical outcome of the chilling stress research was the ranking of chilling tolerance in soybean genotypes probed by the O-J-I-P chlorophyll fluorescence transient (Strauss et al. 2006).

During the period 2002-2008 several investigations on the effect of air pollution on natural vegetation and crop plants were undertaken. This work was initially done in collaboration with the Helmholz Environmental Research Centre, Leipzig-Halle, Germany and the
Atmospheric Chemistry Research Group of the NorthWest University. Various publications appeared on subjects such as the constraints on photosynthesis of $\mathrm{C}_{3}$ and $\mathrm{C}_{4}$ crop plants by trichloroacetic acid and the effect of fluorinated hydrocarbons on $\mathrm{C}_{3}$ and $\mathrm{C}_{4}$ crop plants (Smit et al. 2008). Studies using OTCs included the physiology of $\mathrm{SO}_{2}$ injury and the interaction thereof with drought stress in soybean, comprising the measuring of effects on photosystem II structure and function, photosynthetic gas exchange, Rubisco activity, water relations and nitrogen fixation (Heyneke et al. 2012). The constraints imposed by elevated levels of tropospheric ozone on crop plants were also studied employing the OTC system. Being able to, in addition, regulate the $\mathrm{CO}_{2}$ concentration of the air in the OTCs allowed assessment of the effect of elevated atmospheric $\mathrm{CO}_{2}$ concentrations to obtain insight into the effects of increased atmospheric $\mathrm{CO}_{2}$ levels associated with global warming (Maliba et al. 2019).

Jacques Berner joined Botany as plant physiologist in 2007. Currently, the research of Berner is directed towards the acclimation strategies of new climate resilient crops, like quinoa and amaranth. Prompt fluorescence and modulated $820 \mathrm{~nm}$ reflection are extensively used to evaluate biotypes with stress tolerance. His skills for the study of the ecophysiology of plants in vivo and in situ, were also successfully applied in studies on 
environmental stress exerted on plants of the Namib Desert (Krüger et al. 2017; Berner et al. 2021).

\section{Terrestrial plant ecology}

Ecological studies began in 1963 after Koos van Wyk completed his $\mathrm{PhD}$ and started with research on degradation of pastures. In 1979 he founded the Institute for Ecological Research with external funding that focused initially on the rehabilitation of road verges, but later also on mine tailings. This institute went through a number of name changes and was terminated under the name Research Institute for Rehabilitation Ecology (Eco-Rehab) in 2005. From 1982 to 1988, George Bredenkamp did extensive phytosociological research on grasslands and savannas and several papers were published from this research (e.g. Bredenkamp et al. 1989; Bredenkamp \& Bezuidenhout 1990).

After the appointment of Ockie Bosch as the head of the Department in 1986, the focus was to develop an integrated approach so that all the disciplines in Botany functioned as a unit to encourage collaboration between all scientists in studying community ecology in a dynamic environment.

Johan Booysen, a computer modeler and systems ecologist, joined the Department in 1990. He integrated the community ecology thinking of Bosch into a user friendly computer program to study how the changes in the environment due to climate and management impacts lead to land degradation. This program was named the Integrated System for Plant Dynamics, which required inputs from all sections of Botany, but especially the plant and agricultural ecologists (Kellner \& Booysen 2000).

The models of Bosch focused on the influence that management practices have on natural and agricultural ecosystems. To promote sustainable land management, the research focus was on systems ecology, and in collaboration with EcoRehab, it became possible to also address the restoration of degraded rangelands.

Klaus Kellner was appointed at the PU for CHE in 1988 to carry out research on land degradation and rehabilitation ecology in arid- and semi-arid regions of South Africa. He also represented South Africa as the Science and Technology Correspondent (STC) in the Committee for Science and Technology, a subsidiary body of the United Nations Convention to Combat Desertification (UNCCD), served as president of the STC and represented the African continent at the UNCCD. He was also appointed by the UNCCD to global committees regarding the study of the impacts and control of Desertification, Land Degradation and Drought (DLDD), as well as what technologies can be implemented to restore/rehabilitate these lands. This included the ad hoc Working Group on Scientific Advice (AGSA), which was formed to identify strategies to bridge the gap between rangeland scientists and policy makers working in the environment (Akhtar-Schuster et al. 2016). DLDD research in terrestrial ecology excelled at NWU and many post-graduate studies and projects followed for government departments in South Africa. International collaboration with organisations from Germany, Namibia, Spain and other European Union countries followed, regarding rangeland restoration after the control of woody shrub encroachment (bush encroachment) in arid- and semi-arid rangelands (Harmse et al. 2016). Although the initial projects were broad, they soon focused more on the western parts of South Africa, as well as the southern parts of Namibia and Botswana (Kellner et al. 2018). Pieter Malan of the Mahikeng campus collaborated with expertise in bush encroachment and restoration after the control of woody invasive species.

Research on land degradation and restoration ecology was extended to include aspects of climate change and the socio-economics of the land users applying sustainable land management, especially in the Kalahari region (Kellner \& Bosch 2003). One of the main aims of the UNCCD is to develop a land degradation neutral world, which means that the land that is prone to desertification should be restored after detailed monitoring of the parameters causing the degradation or desertification (Von Maltitz et al. 2019).

Research on grassland and savanna ecosystem dynamics and resilience was expanded from 2012, when Frances Siebert joined Botany. Her relationships with South African National Parks and the Ndlovu (i.e. savanna) node of the South African Environmental Observation Network supported long-term vegetation monitoring in Lowveld savanna. These projects led her to identify the need for an improved understanding of the ecology of forbs, a neglected plant life-form in savanna and grassland (Siebert \& Dreber 2019), as they are often perceived as weeds and indicators of land degradation. Forbs, however, provide important forage stability to a wide array of herbivores (Siebert \& Scogings 2015). This research has put her on the forefront of international networks working on this topic. She has initiated a forb ecology research consortium with research partners from Brazil, Germany, the Netherlands and national associates, which has led to inclusion in other international working groups, such as the Tropical and Sub-tropical Savanna Plant Functional Traits working group, the International Grassland Restoration working group and the Grazing Exclosure Consortium.

\section{Aquatic Sciences}

Aquatic research in Botany includes algal diversity in relation to water quality parameters, including inorganic and organic pollutants. This research focus was established at the former PU for CHE by Braam Pieterse 
in 1994. At that stage the aquatic research team consisted of Pieterse and four postgraduate students, namely Sanet Janse van Vuuren, Antoinette Vermeulen, Annelie Swanepoel and Danie Traut. Initially, aquatic research primarily focused on the diversity of algae and environmental variables influencing their growth and succession in the Vaal River system (Janse van Vuuren \& Pieterse 2005). Over time, especially with the appointment of aquatic scientists from other institutions, the research expanded to include other river systems, dams, and various other habitats throughout the country, and also other research subjects within aquatic sciences.

During 1995, Janse van Vuuren was appointed as junior lecturer in the Department of Botany. Although her early-career research focused primarily on the taxonomy, diversity and ecology of phytoplankton in various freshwater systems throughout the country, she was later also involved in studies of algae in water purification plants, the development of harmful algal blooms (HABs) and aerophytic algae growing against cave walls. Her research culminated in a book on the identification of common freshwater algae (Janse van Vuuren et al. 2006), as well as two chapters in a book on freshwater life (Griffiths et al. 2015).

Sandra Barnard joined the water research group as a lecturer in the Department of Botany in 1996. She initiated a physiological and molecular biological focus in the existing research on algae and this approach later formed an integrated part of aquatic research at the NWU (Conradie \& Barnard 2012). Barnard also published research papers about water quality and pioneered research to predict the dynamics and potential of HABs (Van Ginkel et al. 2007; Swanepoel et al. 2016). International cooperation, including a successful student exchange programme, was established between South Africa and Finland (2002-2005).

During 2000, Arthurita Venter completed her PhD on Oscillatoria simplicissima Gomont - a potentially toxic cyanobacterium that often forms blooms in South African freshwaters. She was later appointed as an administrative officer in Botany and continued to author several papers on the diversity of algae and cyanobacteria not only in aquatic, but also terrestrial environments (Venter et al. 2013). She is currently considered as a pioneer in understanding the biodiversity of biological soil crusts found on serpentine and mine tailings in South Africa (Venter et al. 2018).

Jonathan Taylor became interested in algae when he first studied these organisms during his first year Botany lectures at the PU for CHE in 1997. His interest eventually led to postgraduate studies in Phycology (the study of algae), during which he became interested in a particular group of algae, the diatoms, which are excellent bio-indicators of environmental conditions. As part of his PhD thesis he tested the application of diatom-based pollution indices, developed for northern hemisphere conditions, in southern hemisphere waters. This led to several publications about the application of diatoms as water quality indicators in South Africa (e.g. Taylor et al., 2007). Today Taylor is known for his work on the taxonomy and ecology of the diatoms from central and southern Africa. He described or contributed to the description of three new diatom genera, 19 new diatom species and three new red algal species. In addition, several diatom species have been named in his honour, namely Luticola taylorii Levkov, Metzeltin \& Pavlov, Nitzschia taylorii Alakananda, Hamilton \& Karthick, and Muelleria taylorii Van de Vijver \& Cocquyt.

Taylor is also curator of the South African National Diatom Collection (SANDC) (Table 1) that was started in 1950 by Béla Cholnoky from the University of Pretoria, later from the Council of Scientific and Industrial Research (CSIR). Other well-known phycologists who contributed to the diatom collection were Robert ('Archie') Archibald, Ferdinand Schoeman (both students of Cholnoky) and Malcolm Giffen (University of Fort Hare). Over the years the national collection also received donations from many scientists abroad and thus contains not only South African material but a large selection of material from around the world. The CSIR donated the collection to the South African Institute for Aquatic Biodiversity (SAIAB) in 2009 to ensure its long term preservation. SAIAB, in turn, has loaned the collection to the NWU in an open-ended agreement (Taylor et al. 2011) as the NWU was becoming a centre for diatom studies (especially taxonomy) in the mid-2000s. The collection, now lodged in the Botany department, has since its move been actively digitised, further catalogued and the type material of many South African species has been investigated. The SANDC is now also a registered herbarium.

Anatoliy Levanets, originally from the Ukraine, joined the research team as a postdoctoral fellow from 2003 to 2006. His experience and knowledge about the diversity of soil and other terrestrial algae complimented existing research on aquatic algae, and it led to several studies on the role that soil algae fulfill in the rehabilitation of mine dumps. The effect of various land-uses, such as effluents of mines containing high metal concentrations, directly influences the morphology and diversity of algal species and therefore research on this subject is extremely important. As part of their studies Levanets and Taylor described three new terrestrial diatom species (Microcostatus schoemanii Taylor, Levanets, Blanco \& Ector, M. cholnokyi Taylor, Levanets, Blanco \& Ector and M. angloensis Taylor, Levanets, Blanco \& Ector) from South Africa (Taylor et al. 2010). In addition to his interest in terrestrial algae, Levanets is also interested in a particular group of freshwater green algae (desmids) and he published an annotated and illustrated list of desmids of southern Africa (Levanets \& Van Rensburg 2011).

Information presented in the previous paragraphs illustrates the wide scope of freshwater and algal related 
research within the subject group Botany. Freshwater research at many other universities is limited, as most are situated in coastal areas and focus more on marine algae and marine research.

\section{Urban and settlement ecology}

This research discipline was initiated in 1998 with the completion of the $\mathrm{PhD}$ thesis of Sarel Cilliers on the phytosociology of the city of Potchefstroom under the supervision of George Bredenkamp. This was the first-ever study on the description of plant communities in different land-use areas in an urban setting in South Africa. At that time no other ecologist at any African university was interested in the ecology of urban open spaces. Publications from this thesis described plant communities in land-use areas such as vacant lots, intensively managed areas, railway reserves, natural and semi-natural grasslands and woodlands, wetlands and roadside verges. The paper on roadside verges (Cilliers \& Bredenkamp 2000) was the most influential publication of all of them. These studies also formed the basis for mapping urban biotopes (habitats) in Potchefstroom to provide ecological data for conservation-orientated planning and management of urban open spaces (Cilliers et al. 2004). Moreover, the Tlokwe City Council used these biotope maps in the development of the spatial development framework of the city.

This initial start led to a focus on the investigation of plant diversity patterns and processes in small and medium-sized cities. Two clear directions were followed, namely fragmented natural grasslands along an urbanisation gradient using a landscape ecological approach, and home and community gardens along socio-economic gradients. Firstly, a Master's degree student, Marié du Toit refined a methodology developed in Melbourne, Australia to quantify the urbanisation gradient in Klerksdorp (Du Toit \& Cilliers 2011). This approach was widely used in other studies at the NWU and also globally. Du Toit later completed a PhD and is currently a postdoctoral fellow at the NWU. Important findings from the fragmented grasslands research have indicated that urban grasslands are as important as natural grasslands for conservation as they both play an important role in the fine-scale landscape functioning of grasslands (Van der Walt et al. 2015). Research on the dynamics of these grasslands also indicated that despite any current sign of biotic homogenisation they are facing potential extinction debts (Du Toit et al. 2020). Moreover, this study also showed that the indigenous forb species diversity is declining indicating that better management, including urban grassland restoration, is necessary (Du Toit et al. 2020).

Secondly, the growing awareness of the importance of gardens in the urban green infrastructure led to several postgraduate studies under the supervision of Stefan Siebert and Sarel Cilliers. These studies focussed on biodiversity conservation and the provision of ecosystem services that contribute towards human health and well-being. Subsequent publications focussed on garden diversity patterns and their drivers in deep-rural, rural, peri-urban, urban and metropolitan areas. Of these, a paper on the importance of socio-economics as drivers of plant diversity of gardens (Lubbe et al. 2010) was regarded as one of four key papers in a recent global study, which included a meta-analysis of publications on the relationship between socio-economic inequality and biodiversity. Other garden studies included investigations on garden layout and design, the provision of ecosystem services and the potential to study community gardens (e.g. health clinic gardens) in the North-West province as complex social-ecological systems to enhance resilience in a changing world (Cilliers et al. 2018).

Consequently, a large database was amassed on local urban plant diversity. The expertise developed in this research group have led to an intensive involvement in several international collaborative studies with researchers from several universities in Australia, Brazil, Chile, Finland, Germany, Hungary, Sweden, UK and USA. Two global networks that this research group is actively involved in are Urban Biodiversity Network (UrBioNet) and Global Urban Soil Ecology and Education Network (GLUSEEN). UrBioNet, is a global biodiversity network that supports urban biodiversity research, monitoring and practice in three working groups, namely social-ecological linkages, urban biodiversity patterns and traits, and urban biodiversity monitoring and planning (urbionet.weebly.com). GLUSEEN focuses on the study of urban soil ecological systems (www.gluseen.org). As part of this network a comparative study was completed on soil biodiversity and soil decomposition in public green spaces, ruderal areas, remnant natural areas and natural areas in five cities in four countries (including South Africa). From both networks several leading papers were published (e.g. Aronson et al. 2016; Epp Schmidt et al. 2017).

Furthermore, this research group is also involved in transdisciplinary research and training in collaboration with urban planners and landscape architects locally and globally. The main focus is on green infrastructure planning and several projects such as the value of urban green areas and the importance of ecosystem services in planning and design have been completed (e.g. Ahern et al., 2014). Research on these issues has also led to the development of a booklet for the SA Cities Network suggesting ways of guiding future green infrastructure planning and management in South Africa (www.sacities.net).

\section{New specialisation fields: Geoecology and Proteomics}

Botany at the NWU has its roots in the study of plant morphology, plant physiology, plant ecology and plant 
diversity. With the appointment of Stefan Siebert as curator of the herbarium in 2007, this scope broadened to include phytogeography. This research interest allowed him to collaborate since 2010 on interdisciplinary biodiversity projects, primarily for the South African National Biodiversity Institute and the South African Environmental Observation Network. He specifically investigated how the diversity and distribution patterns of plants and arthropods are altered when ecosystems are exogenously disturbed in agricultural, mining and urban environments (Lubbe et al. 2010; Siebert et al. 2021). During this time he also established geoecology as a new research field at the university. Extensive collaboration with Nishanta Rajakaruna (California Polytechnic State University) and Marthie Coetzee (Geology subject group, NWU) through the National Geographic Society has led to various research projects involving geobotanical surveys (Boneschans et al. 2015), heavy metal accumulation by plants (Siebert et al. 2018) and biological soil crusts (Venter et al. 2018) on ultramafic rocks. He has expanded his research to include lichens and is currently studying the interactions of plants with other rock types, such as banded ironstone, dolomite and gypsum.

The establishment of Botany on the Mahikeng campus of NWU in 2017 has strengthened the subject group's expertise in plant biology and biotechnology. Oziniel Ruzvidzo and Tshegofatso Dikobe have a strong research interest in plant proteins. Proteomics is therefore the youngest research discipline in Botany at the NWU. They collaborate internationally with the University of Perugia (Italy), and the Whenzhou-Kean University (China). Specifically, their work on adenylate cyclases is important as these enzymes are increasingly recognised as essential parts of many plant processes including biotic and abiotic stress responses (Chatukuta et al. 2018). It is increasingly clear that plant genomes encode numerous complex multi-domain proteins that harbour functional adenylyl cyclase. These proteins have well-documented roles in plant development and responses to the environment. Hence, Botany staff on the Mahikeng campus conduct research to better understand the intramolecular mechanisms that govern the cellular and biological functions of these proteins (Ruzvidzo et al. 2019). The findings of their work have vast applications in agriculture.

\section{Conclusions}

For the past 100 years Botany at the NWU contributed considerably to varied research and development disciplines. From the discussion of the research undertaken over the years it can be seen that the focus was initially on plant physiology and plant systematics, and plant ecology has been included since 1963. Over the last two decades more emphasis has also been placed on different sub-disciplines in ecology studying natural, degraded and anthropogenic ecosystems in terrestrial and aquatic environments. Botany teaching and research at the NWU (and the former PU for CHE) has over the years and is currently playing a major role in the development, and contributing to the prestigious status, of Botany in South Africa. Researchers at NWU are local and international leaders in their specific fields of expertise in e.g. plant function, diversity, taxonomy, aquatic ecology, urban ecology, land degradation and ecological restoration of natural and disturbed terrestrial and aquatic ecosystems. Scientists from various disciplines are also actively involved in collaborative national and international research and development projects and forums. It has always been a priority at NWU to keep a good balance between basic and applied science within curricula and research.

NWU biological scientists have been and are involved in projects and programmes to better understand landuse changes due to natural (e.g. climate) and anthropogenic (e.g. management) impacts. Indigenous plant diversity is mostly diminished and plant distribution patterns altered when land-use change is enforced by people to meet their developmental and economic needs. Research results indicated that land-use changes dilute the trait redundancy of ecosystems and the extent of ecosystem services that can be provided by affected ecosystems. Recent studies on herbaceous dynamics, with a specific focus on forbs, contributed to an improved understanding of ecosystem resilience in areas exposed to land-use change, especially sub-tropical grasslands and savannas. Different ecological restoration methods have been developed and tested in arid- and semi-arid natural rangelands and implementing them improves vegetation condition, contributes to increased grazing capacity and enhances sustainable land management practices. Urban ecological studies have contributed to knowledge of the ecosystem services provided by the urban green infrastructure and assist in the development of a conservation-oriented planning, design and management approach in South African cities. Research on rivers has indicated that their water quality is modified by activities and processes in the water and in the surrounding catchment area and directly influence phytoplankton and benthic assemblages. Furthermore, research results have also contributed to the development and application of diatom indices for routine riverine water quality biomonitoring and the establishment of the South African Diatom Index (SADI), which reflects land-use changes and pollution events in South African rivers. Plant ecophysiological investigations quantified the impacts of elevated carbon dioxide, air pollution and drought stress on crops and native plants.

Research in Botany at the NWU also contributes immensely to the improvement of the health and well-being of South Africans from different cultural groups and socio-economic statuses. Monitoring of species 
functional diversity and patterns in natural and degraded ecosystems is allowing us to determine when land-use change negatively affects ecosystem functions and the services they provide to humans. It prompts for action to address the subsequent degradation and to put in place mitigation measures to restore the lost functions and services. Studying urban areas as complex and adaptive social-ecological systems enables us to address the specific ecosystem service needs of all residents, working towards the development of climate- and food-resilient cities, towns and settlements. Research on the ecology and functioning of forbs in grassy ecosystems aims to secure future ecosystem goods, services and functions. Forbs as a plant group are important for forage stability during dry seasons, pollinator resources for food security and biodiversity. Research has also contributed to the sustainable use of the large component of forbs that are traditionally used for medicine and/or food items for rural livelihoods. By understanding changes in phytoplankton and benthic assemblages of our rivers, and biomonitoring of water quality using inexpensive methods, a rapid response to pollution events enables management interventions leading to improved river water quality. Local communities can therefore be protected from the nuisance of toxins produced by harmful algal blooms and water treatment plants can produce safe drinking water. From ecophysiological studies it is possible to identify and introduce alternative climate-resilient crops, which may in future provide the much-needed food and nutrient security for sub-Saharan Africa.

\section{Acknowledgements}

The authors of this paper wish to acknowledge the contributions of other Botany colleagues for providing information about their fields of research, namely Sandra Barnard, Jacques Berner, Frances Siebert and Jonathan Taylor. The NWU Records, Archives and Museum is thanked for allowing the use of archival material and images. The three reviewers of this manuscript are thanked for their useful comments, corrections and suggestions, which contributed greatly towards the improvement of the text.

\section{Authors contributions}

All the co-authors wrote sections of the paper. SC wrote sections and was responsible for integration of all the sections and coordination of the paper.

\section{References}

Ahern, J., Cilliers, S.S. \& Niemelä, J., 2014, 'The concept of ecosystem services in adaptive urban planning and design: A framework for supporting innovation', Landscape and Urban Planning, 125, 254-259. https://doi.org/10.1016/j. landurbplan.2014.01.020

Akhtar-Schuster, M., Amiraslani, F., Diaz Morejon, C.F., Escadafal, R., Fulajtar, E., Grainger, A., Kellner, K., Khan, S.I., Perez Pardo, O., Sauchanka, U., Stringer, L.C., Reda, F. \& Thomas, R.J., 2016, 'Designing a new science-policy communication mechanism for the UN Convention to Combat Desertification', Environmental Science \& Policy, 63, 122-131. DOI: 10.1016/j.envsci.2016.03.009

Aronson, M.F.J, Nilon, C.H., Lepczyk, C.A., Parker, T., Warren, P.S., Cilliers, S.S., Goddard, M.A., Hahs, A., Herzog, C., Katti, M., La Sorte, F.A., Williams, N.S.G. \& Zipperer, W., 2016, 'Hierarchical Filters determine community assembly of urban species pools', Ecology, 97(1), 2952-2963. doi: 10.1002/ecy. 1535

Berner, J.M., Cloete, H. \& Shuuya, T., 2021, 'A baseline assessment of the photsynthetic potential of Welwitschia mirabilis using the JIP-test for monitoring and conservation purposes', Bothalia 51(1): 133-139 (hardcopy); 1-7 (online) [this issue].

Bester, S.P. \& Nicholas, A., 2018, New combinations in Stenostelma (Apocynaceae-Asclepiadoideae) and two novel species from South Africa', Phytotaxa, 361(1), 41-55. 10.11646/phytotaxa.361.1.3

Boneschans, R.B., Coetzee, M.S. \& Siebert, S.J., 2015, 'A geo- botanical investigation of the Koedoesfontein Complex, Vredefort Dome, South Africa', Australian Journal of Botany, 63, 324-340. DOI: 10.1071/BT14267

Botha P.J., 1950, 'The effect of time of pre-exposure, temperature of pre-exposure and concentration of the host factor on the germination of the seed of Alectra vogelii Benth. ', Journal of South African Botany, 16, 23-29.

Bredenkamp, C.L. \& Botha, D.J., 1993, 'A synopsis of the genus Vitex L. (Verbenaceae) in southern Africa', South African Journal of Botany, 59(6), 611-622.

Bredenkamp, G.J. \& Bezuidenhout, H., 1990, 'The phytosociology of the Faan Meintjies Nature Reserve in the western Transvaal grassland, South Africa.' South African Journal of Botany, 56(1), 54-64.

Bredenkamp, G.J., Joubert, A.F. \& Bezuidenhout, H., 1989, 'A reconnaissance survey of the vegetation of the plains in the Potchefstroom-Fochville-Parys area', South African Journal of Botany, 55(2), 199-206.

Chatukuta, P., Dikobe, T. B., Kawadza, D. T., Sehlabane, K. S., Takundwa, M. M., Wong, A., Gehring, C. \& Ruzvidzo, O., 2018, 'An Arabidopsis clathrin assembly protein with a predicted role in plant defense can function as an adenylate cyclase', Biomolecules, 8(2), 15. DOI: 10.3390/ biom8020015

Cilliers, S.S. \& Bredenkamp, G.J., 2000, 'Vegetation of roadside verges on an urbanization gradient in Potchefstroom, South Africa', Landscape and Urban Planning, 46, 217-239. Cilliers, S.S., Müller, N. \& Drewes, J.E., 2004, 'Overview on ur- 
ban nature conservation: situation in the western-grassland biome of South Africa', Urban Forestry \& Urban Greening, 3, 49-62. doi:10.1016/j.ufug.2004.04.003

Cilliers, S.S., Siebert, S.J., Du Toit, M.J., Barthel, S., Mishra, S., Cornelius, A. \& Davoren, E., 2018, 'Garden ecosystem services of Sub-Saharan Africa and the role of health clinic gardens as social-ecological systems', Landscape and Urban Planning, 180, 294-307. DOI: 10.1016/j.landurbplan.2017.01.011

Conradie K.R. \& Barnard S., 2012, 'The dynamics of toxic Microcystis strains and microcystin production in two hypertrofic South African reservoirs', Harmful Algae, 20, 1-10. DOI: 10.1016/j.hal.2012.03.006

Du Toit, M. \& Cilliers, S.S., 2011, 'Aspects influencing the selection of representative urbanization measures to quantify urban-rural gradients' Landscape Ecology, 26, 169-181. DOI: 10.1007/s10980-010-9560-4

Du Toit, M.J., Kotze, D.J. \& Cilliers, S.S., 2020, 'Quantifying long-term urban grassland dynamics: biotic homogenization and extinction debts', Sustainability, 12, 1989. DOI: 10.3390/su12051989

Epp Schmidt, D.J., Pouyat, R., Szlavecz, K., Setälä, H., Kotze, D.J., Yesilonis, I., Cilliers, S.S., Hornung, E., Dombos, M. \& Yarwood, S.A., 2017, 'Urbanization leads to the loss of ectomycorrhizal fungal diversity and the convergence of archaeal and fungal soil communities', Nature Ecology \& Evolution, 1, 0123.

Goossens, A.P., 1941, 'A new genus of South African Gramineae', South African Journal of Science, 37, 183-191.

Goossens, A.P. \& Phillips, E.P., 1932, 'The genus Anthephora Schreb.', Transactions of the Royal Society of South Africa, 20(2), 189-200.

Griffiths C., Day J. \& Picker M., 2015, Freshwater Life - A field guide to the plants and animals of southern Africa. Cape Town: Struik Nature.

Harmse, C.J., Kellner, K. \& Dreber, N., 2016, 'Restoring productive rangelands: a comparative assessment of selective and non-selective chemical bush control in a semi-arid Kalahari savanna', Journal of Arid Environments, 135, 39-49.

Heyneke, E., Strasser, R.J., Strauss, A.J. \& Krüger, G.H.J., 2012, 'Open-top chamber facility to study air pollution impacts in South Africa. Part II: $\mathrm{SO}_{2}$-drought interactions on yield, photosynthesis and symbiotic nitrogen fixation in soybean', South African Journal of Plant \& Soil, 29(1), 9-23. https://doi.org/10.1080/02571862.2012.688373

Janse van Vuuren, S. \& Pieterse, A.J.H., 2005, 'The use of multivariate analysis as a tool to illustrate the influence of environmental variables on phytoplankton composition in the Vaal River', African Journal of Aquatic Sciences, 30(1), 17-28. https://doi.org/10.2989/16085910509503830

Janse van Vuuren, S., Taylor, J., Gerber, A. \& Van Ginkel, C., 2006, Easy identification of the most common freshwater algae. A guide for the identification of microscopic algae in South African freshwaters. Potchefstroom: North-West University and Department of Water Affairs and Forestry.

Jooste, W., 2017, 'Plantkunde: Die wetenskap van skoonheid' in Van Eeden, E.S. (red.) 'n Bekroonde nalatenskap: die Fakulteit Natuurwetenskappe van die NWU oor 100 jaar. Potchefstroom: Ivyline Academic Publishers, pp. 91-113.

Kellner, K. \& Booysen, J., 2000, 'ISPD - integrated system for plant dynamics: a decision support system for rangeland management' in Ringrose, S. \& Chanda, R. (eds.) Towards sustainable management in the Kalahari region: some essential background and critical issues. Gaborone: Directorate of Research and Development, University of Botswana, pp. 151-155.

Kellner, K. \& Bosch, O.J.H., 2003, 'The value of local and indigenous knowledge for the development of information systems for conservation management' in Lemons, J., Victor, R. \& Schaffer, D. (eds.) Conserving biodiversity in arid regions: best practices in developing nations. New York: Springer, pp. 105-118.

Kellner, K., Von Maltitz, G., Seely, M., Atlhopheng, J. \& Lindeque, L., 2018, 'South African arid lands: current status and future prospects' in Guar, M.K. \& Squires, V.R. (eds.) Climate variability impacts on land use and livelihoods in drylands. Cham: Springer, pp. 243-260.

Krüger G.H.J., Jordaan A. Tiedt L.R., Strasser R.J., Kilbourn Louw M. \& Berner J.M., 2017, 'Opportunistic survival strategy of Welwitschia mirabilis: Recent anatomical and physiological studies elucidating stomatal behaviour and photosynthetic potential', Botany, 95, 109-1123. https:// doi.org/10.1139/cjb-2017-0095

Krüger, G.H.J., Tsimilli-Michael, M., \& Strasser, R.J., 1997, 'Light stress provokes plastic and elastic modifications in structure and function of photosystem II in Camellia leaves', Physiologia Plantarum, 101, 265-277.

Lebatha, P., Buys, M.H. \& Stedje, B., 2006, 'Ledebouria, Resnova and Drimiopsis: a tale of three genera', Taxon, 55(3), 643-652. https://doi.org/10.2307/25065640

Levanets, A. \& Van Rensburg, L., 2011, Desmids of Southern Africa: An annotated and illustrated list. Potchefstroom: Platinum Press.

Lubbe, C.S., Siebert, S.J. \& Cilliers, S.S., 2010, 'Political legacy of South Africa affects the plant diversity patterns of urban domestic gardens along a socioeconomic gradient', Scientific Research and Essays, 5(19), 2900-2910.

Maliba, B.G., Inbaraj, P.M. \& Berner, J.M., 2019, 'Photosynthetic responses of canola and wheat to elevated levels of $\mathrm{CO}_{2}, \mathrm{O}_{3}$ and water deficit in open-top chambers', Plants, 8(6), 171. https://doi.org/10.3390/plants8060171

Ruzvidzo, O., Gehring, C. \& Wong, A., 2019, 'New perspectives on plant adenylyl cyclases', Frontiers in Molecular Biosciences, 6, 136. https://doi.org/10.3389/ fmolb.2019.00136

Siebert, F. \& Dreber, N., 2019, 'Forb ecology research in dry African savannas: Knowledge, gaps, and future perspectives', Ecology and Evolution, 9, 7875-7891. https://doi. org/10.1002/ece3.5307

Siebert, F. \& Scogings, P., 2015, 'Browsing intensity of herbaceous forbs across a semi-arid savanna catenal sequence', South African Journal of Botany, 100, 36-74. DOI: 10.1016/j.sajb.2015.05.007

Siebert, F., Van Staden, N., Komape, D.M., Swemmer, A.M. \& Siebert, S.J., 2021, 'Effects of land-use change on herbaceous vegetation in a semi-arid Mopaneveld savannah', Bothalia, 51(1): 107-132 (hardcopy); 1-26 (online) [this issue].

Siebert, S. J., Retief, E., Van Wyk, A.E. \& Struwig, M., 2010, 'A new species of Polygala (Polygalaceae) from ultramafic soils in Sekhukhuneland, South Africa, with notes on its ecology', South African Journal of Botany, 76(2), 345-353.

Siebert, S.J., Schutte, N., Bester, S.P., Komape, D.M. \& Rajakaruna, N., 2018, 'Senecio conrathii N.E.Br. (Asteraceae), 
a new hyperaccumulator of nickel from serpentinite outcrops of the Barberton Greenstone Belt, South Africa', ECOlogical Research, 33, 651-658. https://doi.org/10.1007/ s11284-017-1541-5

Smit, M.F., Cilliers, S.S., Siebert, S.J. \& Willis, C.K., 2011, 'The North-West University Botanical Garden: The resurgence of this North-West Province haven of biodiversity', Veld \& Flora, 97(1), 11-13.

Smit, M.F., Van Heerden, P.D.R., Pienaar, J.J., Weissflog, L., Strasser, R.J. \& Krüger, G.H.J., 2008, 'Effect of trifluoroacetate, a persistent degradation product of fluorinated hydrocarbons, on $\mathrm{C}_{3}$ and $\mathrm{C}_{4}$ crop plants', Plant Physiology and Biochemistry, 47, 623-634.

Strauss, A.J., Krüger, G.H.J., Strasser, R.J. \& Van Heerden, P.D.R., 2006, 'Ranking of dark chilling tolerance in soybean genotypes probed by the chlorophyll a fluorescence transient O-J-I-P', Environmental and Experimental Botany, 56, 147-157.

Struwig, M., \& Siebert, S.J., 2013, 'A taxonomic revision of Boerhavia (Nyctaginaceae) in southern Africa', South African Journal of Botany, 86, 116-134. https://doi.org/10.1016/j. sajb.2013.02.172

Swanepoel, A., Barnard, S., Recknagel, F. \& Cao H., 2016, 'Evaluation of models generated via hybrid evolutionary algorithms for the prediction of Microcystis concentrations in the Vaal Dam, South Africa', Water SA, 42(2), 243-252.

Taylor, J.C., Bills R. \& Harding, W.R., 2011, 'The South African Diatom Collection: an update', African Journal of Aquatic Science, 36(1), 113-114.

Taylor, J.C., Levanets, A., Blanco, S. \& Ector, L., 2010, 'Microcostatus schoemanii sp. nov., M. cholnokyi sp. nov. and $M$. angloensis sp. nov.: Three new terrestrial diatoms (Bacillariophyceae) from South Africa', Phycological Research, 58(3), 177-187.

Taylor, J.C., Prygiel, J., Vosloo, A., De La Rey, P.A., \& Van Rensburg, L., 2007, 'Can diatom based pollution indices be used for bio-monitoring in South Africa? A case study of the Crocodile West and Marico water management area', Hydrobiologia, 592, 455-464.

Theunissen, J.D., 1992, 'An ecosystematic investigation of Themeda triandra (Poaceae: Andropogoneae) in the semi-arid grasslands of southern Africa', Journal of Arid Environments, 23(1), 35-44.
Van Der Walt, L., Cilliers, S.S., Kellner, K., Du Toit, M.J. \& Tongway, D., 2015, 'To what extent does urbanisation affect fragmented grassland functioning?', Journal of Environmental Management, 151, 517-530. doi: 10.1016/j. jenvman.2014.11.034

Van Ginkel, C., Cao, H., Recknagel, F., \& Du Plessis, S., 2007, 'Forecasting of dinoflagellate blooms in warm-monomictic hypertrophic reservoirs in South Africa by means of rulebased agents', Water SA, 33(4), 1-8.

Van Heerden, P.D.R., Krüger, G.H.J., Loveland, J.E., Parry, M.A.J. \& Foyer, C.H., 2003, 'Dark chilling impose metabolic restrictions on photosynthesis in soybean', Plant Cell \& Environment, 26, 323-337.

Van Niekerk, C.J.G. \& Siebert, S.J., 2018, 'A second chance on life: Khadia beswickii', PlantLife, 46,9

Van Rensburg, L. \& Krüger, G.H.J., 1993a, 'Comparative analysis of differential drought stress-induced inhibition of, and recovery in, carbon dioxide fixation: Stomatal and non-stomatal limitations in Nicotiana tabacum L.', Journal of Plant Physiology, 142, 296-306.

Van Rensburg, L., Krüger, G.H.J. \& Krüger, H., 1993b, 'Proline accumulation as drought-tolerance selection criterion: its relationship to membrane integrity and chloroplast ultrastructure in Nicotiana tabacum L.', Journal of Plant Physiology, 141, 188-194.

Venter, A., Barnard, S., Dickinson, M.A., Janse van Vuuren, S., Levanets, A. \& Taylor, J.C., 2013, 'Planktonic algae and cyanoprokaryotes as indicators of ecosystem quality in the Mooi River system in the North-West Province, South Afri-

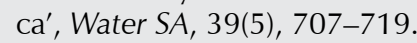

Venter, A., Siebert, S.J., Rajakaruna, N., Barnard, S., Levanets, A., Ismail, A., Allam, M., Peterson, B. \& Sanko, T., 2018, 'Biological crusts of serpentine and non-serpentine soils from the Barberton Greenstone Belt of South Africa', Ecological Research, 33, 629-640.

Von Maltitz, G.P., Gambizo, J., Kellner, K., Rambau, T., Lindeque, L. \& Kgope, B., 2019, 'Experiences from the South African land degradation neutrality target setting process', Environmental Science and Policy, 101, 54-62.

Whitehead, C.S., Halevy, A.H. \& Reid, M.S., 1984, 'Roles of ethylene and 1-aminocyclopropane-1-carboxylic in pollinated and wound-induced senescence of Petunia hybrida L.', Physiologia Plantarum, 61(4), 643-648. 